Social Work

\& Education

๑๑) SW8E, 2018

Klos, L. (2018). From studying the USA experience in mental health social work to the development of social workers' training program in Ukraine, Social Work and Education, Vol. 5, No. 3., pp. 6-16.

\title{
FROM STUDYING THE USA EXPERIENCE IN MENTAL HEALTH SOCIAL WORK TO THE DEVELOPMENT OF SOCIAL WORKERS' TRAINING PROGRAM IN UKRAINE
}

\section{Liliia Klos,}

Doctor of sciences in pedagogic, associate professor,

Department of Sociology and Social Work,

Lviv Polytechnic

National

University

Lviv, Ukraine

\section{Лілія Клос,}

доктор педагогічних

доиент,

кафедра соиіологіі

соиіальної роботи,

Національний

університет

«Львівська політехніка»,

м. Львів, Украӥна

klosliliya615@gmail.com

ORCID: 0000-0001-9972-7450

УДК 82-312.1

DOI: $10.25128 / 2520-6230.18 .3 .1$

Article history:

Received: October 08, 2018

1st Revision: October 22, 2018

Accepted: October 30, 2018
Abstract. The article is devoted to substantiation of expediency of introduction of a new specialization on preparation of social workers in Lviv Polytechnic. The development of the practice of social work in the field of mental health in the USA is analyzed, and, taking into account the set of criteria the author has proposed its periodization of development of the system of social workers' vocational training for public health care in the United States. The empirical experience of social work in the field of mental health in this country is described and its наук, comparative analysis with Ukrainian realities is carried out. On the basis of the revealed theoretical and methodological $m a$ principles and organizational and methodical features of professional training of social workers for providing social services in the context of solving the problems of mental health protection in the United States, a draft program for the specialization of social workers for mental health care in Ukraine has been proposed. 


\section{Introduction}

Preserving public health as a strategic resource and indicator of a country's defense capability, its competitiveness at the international level is one of the priorities of each state. This is especially true for modern Ukraine in the difficult conditions of Russian military aggression and the associated socio-political crisis. According to the National Institute for Strategic Studies of Ukraine (2015) and the Central Intelligence Agency of the United States (2016) the health status of the Ukrainian population is unsatisfactory: the general mortality rate $(14.46 \%$ - 2nd place in the world after Lesotho), fertility (10.82\% - 182 place), population growth $(-0.6 \%-228$ th place); the population has decreased by almost 9 million people in 25 years of independence; "high extra-mortality" of men and the archaic structure of population mortality are Ukrainian "phenomena". Military actions and the resulting difficulties (more than 1800000 internally displaced people, more than 10000 people killed, 20000 people injured, socio-economic decline, political instability) especially contribute to the aggravation of population mental health problem as one of the key factors of welfare of a modern person in general (Klos L., 2018, p. 38).

Social workers react to all social changes quickly, promote the development of individuals, families, communities, society, their understanding, achieve social justice, improve health and well-being. Effective fulfillment of professional duties by social workers is possible due to their readiness for health-care activity, in particular to work in the field of mental health.

Creative use of the achievements of foreign pedagogical science and practice contributes to the effectiveness of professional training of social workers in mental health. In particular, the experience of the United States is useful. It is recognized as relevant for comparative and pedagogical analysis in this area for objective reasons: a) social work in this country is an industry, divided by the areas of specialists activities and problems of clients; social workers make up $0.25 \%$ of the US population, of which more than $40 \%$ are employed in health; the forecast of the Department of Labor for 2014-2024 points to an increase in the need for specialists by $19 \%$ (Department of Labor, 2016); b) professional education in social work has reached a high level for over a century and is recognized in the world as a model of training; c) the theory and experience of social work practice of the USA is substantiated by experts and disseminated by international professional organizations (IFSW, IASSW); d) professional training of health care social workers reflects the leading trends in the development of education in social work, it is provided with all levels of higher education (bachelor, master, doctor of philosophy), postgraduate and post-doctoral training in conditions of continuing education and use of various interactive forms and teaching methods (Council on Social Work Education, 2015).

The purpose of the article: to substantiate the concept of the program of mental health social workers professional training basing on the results of the analysis of social work development in mental health in the USA and studying the state of the problem in Ukraine.

Objectives of the research: 1) to find out the peculiarities of development of mental health social work and professional training for this activity in the United States; 2) to characterize the state of the problem (assistance in mental health care) in Ukraine; 3) to formulate the conceptual framework of the program of professional training of 
mental health social workers in Ukraine on the basis of the results of studied the recognized positive foreign experience in training of specialists in social work for mental health sphere and taking into account the peculiarities of Ukrainian realities.

Methodology of doing research is based on the leading ideas of the philosophy of education, which contributed to the definition of the methodology of vocational training of social workers for activities in the field of mental health as an integrated system, which is based on interdisciplinarity and integration of knowledge and achievements of various fields (education, social work, medicine, etc.).

To achieve the goal and to solve the problems of the research, a set of theoretical methods was used: analysis, synthesis, comparison, systematization, generalization (used to study the works of foreign and domestic scholars, official and normative documents); comparative (analysis of literature on philosophy, methodology, pedagogy, social work, terminology analysis).

\section{Results}

\section{Development of social work in mental health in the USA}

An analysis of the available source base for this problem is performed and made it possible to establish that social work in mental health, in particular psychiatric social work, is one of urgent and the most developed trends in the practice of social health workers in the United States, Great Britain, Canada, Germany and other countries with significant experience in professional social work. The first social workers in the US hospitals, in particular, in the psychiatric ward of the Massachusetts General Hospital, began practicing in 1903. The empirical experience of mental health social work in the United States illustrates the following figures. In 1983 more than $75 \%$ of medical social workers were employed in hospitals, the practice in mental health was the largest and numbered almost 90000 workers (26.6\%), the largest number of social workers in mental health were involved in the work of the Centers of Mental Health in the community (US. News \& World Report, 2011); in 1995 the number of social workers in mental health increased to $39 \%$ of the members of the NASW, at the beginning of 2000, $76 \%$ of psychiatric hospitals and $86 \%$ of general-purpose emergency hospitals had social services. By the end of 2005, almost $40 \%$ of NASW members identified themselves not as social workers but as mental health professionals (NASW Fact Sheet, 2006).

These clinics operate with the support of private and public funding. The mental health services provided under these conditions can vary significantly from the point of view of intensity and duration. Social workers who work under these conditions can provide direct mental health services and manage cases. Social workers in mental health clinics often work as part of a team. Problems solved by social workers in clinics and ambulatory medical institutions in mental health protection, are associated with stress in everyday life, behavioral disadvantages, emotional crisis, environmental (in the sense of habitat, surroundings) or situational phenomena, disorders of nutrition, parent-child problems, family problems, depression, schizophrenia, bipolar disorder and other disorders of psychics and mental health (General Assemblies of IASSW and IFSW, 2004; NASW Center for Workforce Studies, 2011).

The functions of social workers in psychiatric clinics may depend on a particular role in the institution associated with the position occupied. Possible names of positions, but may vary, "clinical social worker", "licensed clinical social worker", "mental health specialist", "clinician", "therapist", "consultant," "director or case manager." Functions 
that social worker performs in a mental health clinic: 1) definition of client's right to receive services; 2) biopsychosocial assessment and study of social history; 3) assessment of clients' state regarding the use of psychoactive substances, research of the system of support, physical and emotional functioning, financial stability, security, suicidal ideas, etc.; 4) development and implementation of treatment plans and extraction plans, which depend on the client's self-determination; 5) provision of direct therapeutic services, such as individual, family or group therapy in accordance with the mental health problem; 6) provision of crisis management, including safety assessment; 7) protection of the client's right to service; 8) management services, including, but not limited to, redirection to resources such as cooperation with other professionals; 9) promotion of mental health services provided by the clinic to wider community; 10) participation in the writing of grants and assessment of possibilities of attracting or retaining funds for program funding; 11) identifying and solving ethical problems; 12) management, training and supervision of personnel; 13) functioning as part of a multidisciplinary team of specialists (Educational Policy and Accreditation Standards, 2015; NASW Center for Workforce Studies, 2011).

Social work specialists involved in therapeutic mental health process must have a master's degree, be licensed by the state administration where they practice. Their roles vary, depending on the client's problems, characterizing a variety of professional experience. Like social workers in a psychiatric clinic or outpatient clinic, they have a significant burden, so they can experience secondary trauma or emotional stress by helping their clients overcome difficult life situations (NASW Center for Workforce Studies, 2011).

The analysis of wages of social workers in psychiatric health clinics and ambulatory medical institutions showed that wages depend on length of service, type of institution, occupation, country region, etc. Thus, for social workers in mental health with a work experience of 9 years or less, the annual salary (at full time employment) is $\$$ 69,100 , and for employees with an experience of 20 years or more - $\$ 90,000$. The lowest salary of a social worker in mental health in the northeast states is $\$ 78,000$, the highest in the west of the country is \$92,100 (Gibelman M., 2005; NASW Center for Workforce Studies, 2011).

Unlike the aforementioned places of practice of a mental health social worker, a psychiatric social worker of a district health department is selected on the basis of open competition. Working on this position the employee provides professional social work services for treatment of clients requiring mental health care. His main duties include: 1) interviewing individuals, members of their families and / or other significant ones to receive information about family, social, occupational, medical history of life, and also about the dependence and treatment of mental health; 2) planning and implementation of a client's therapy program under the supervision of supervising staff, taking into account the purpose of the client's treatment and the determined priorities, taking into account the duration and maintenance of the therapy; 3) providing psychotherapy for individuals, groups, families and other significant persons; 4) The Lanterman-Petris-Short Act/ it refers to the detention and compulsory treatment of individuals with mental health problems for the safety of others in the community; in large cities these powers are delegated to the director of the district department of mental health) completing the application for an immediate 72-hour stay in a hospital; 5) interviewing people in need of emergency psychiatric help, use of crisis intervention techniques to prevent 
hospitalization and help people fight emotional crisis; 6) acting as a member of a mental health emergency team and / or jointly with the law enforcement / psychiatric emergency medical team to assess the behavior of persons (to determine the state of a mental disorder dangerous to oneself, other, or serious incapacity); 7) developing a Comprehensive Care Program (CCP) to manage or overcome a mental or emotional problem that may include individual, group, family or spousal counseling, case management, and / or referral to another source treatment, such as a psychiatrist, psychologist, vocational or rehabilitation consultant or other institution; 8) provide case management services to provide resources for clients, families, and other significant ones for the purpose of treatment; 9) assisting clients, families and other significant people by discussing their reactions and relationships regarding mental health and related disorders caused by psychoactive substance abuse; explaining what is needed for treatment; calling on all stakeholders to work with each other to solve this problem and minimize the tension that affects social functioning; 10) work with families and other significant ones to gain recognition and participate in treatment recommendations; 11) evaluating the functioning of the client in his habitual environment; 12) participating in the work of multidisciplinary team for discussing and evaluating the nature of the client's problem, assessing the client's progress, and developing the efficiency (California Social Work Education Center, 2016).

In order to take up this position, the desired qualification is a doctorate from an accredited social work school, an experience in postgraduate studies in social work, implemented in an individual, group or family psychotherapeutic assessment at a local mental health institution or psychiatric hospital in the last six years, and should have approvals from the relevant Board of Conduct for participation in extracts permitted by law (see above). This allows you to get a license for work up to 4-6 years, depending on full / part time employment. For examinations of readiness one should pass an exam, it is desirable to achieve a pass point of $70 \%$ or higher (NASW Center for Workforce Studies, 2011).

\section{Development of social workers professional training in the field of mental health in the USA}

The professional training of social workers to work in the field of mental health care in the United States is closely linked to the development of the entire system of training of social workers to health-care and health-promotion activities. Use of a set of criteria (purpose, objectives, principles, values of training, educational institutions, duration of training, programs, students and teachers, training management, educational standards, professional development of specialists), reflecting the characteristics of the system of higher education and the peculiarities of professional training in the field of social work for the health sector, it has been possible to identify and justify the six periods of its development (Klos L., 2018, p. 240).

The professional training of social workers in the US universities for health-care activities is described in the process of evolution from the end of the 18th century up to now, six consecutive periods have been identified, each of which has its own inherent laws. The first period is a volunteer era (the end of the 18th century till the 80s of the 19th century), when the legality of social workers training for health activities in social needs was recognized as a regularity; the second period is a primary disemination (1890s till 1920s) - the establishment of relationship and dependence of the training of social workers on health-care activities from the conditions in which it took place was logical. The third period can be characterised as strengthening of institutionalization (1930-1940- 
ies of the 20th century), marked with establishment of interdependence between the processes of professional training and the development of the personality of a specialist, illustrating events during the economic crisis and the Second World War. The fourth period - the completion of professionalization (50-70-ies of the 20th century), we consider the unity of teaching and learning processes in the training of future social workers for health-care activities. The fifth Period - systematization and new strategies (80-90s of the 20th century) is characterized by regularity of establishing the relationship between training, the real cognitive capabilities of students and their personal needs for professional development. For the sixth period - continuous development (the beginning of the 21 st century till nowadays) - the regularity of the system development is considered to be the establishment of interdependence between the tasks, content, methods and forms of training in the professional training of social workers for activities in health care at a university (Klos L., 2018, pp. 240-243).

\section{Features of the problem of mental health care of population in modern Ukraine: the reality and prospects}

The specific and typical Ukrainian problem of mental health care of citizens in modern conditions is high indicators of lesions of Ukraine's population with posttraumatic stress disorder (PTSD) both among servicemen and among civilians. However, if servicemen are necessarily provided with psychosocial support and other types of care, then the civilian population remains largely without it. According to the Ministry of Defense, PTSD was detected in 60-70 000 veterans of anti-terror military operation of Ukraine's army in state east regions, representing more than $25 \%$ of all participants of hostilities (Awesome statistics, 2017).

At the same time, a number of researchers (Kokun O., Agayev N., Pishko I., Lozinskaya N., Ostapchuk V.) believe that the signs of PTSD have almost 93\% of participants of Ukraine's anti-terror military operation, but it is nor paid proper attention. According to the State Service of Ukraine for Veterans of War and ATO participants, as of January 10, 2017, rehabilitation centers provided social and psychological assistance to 10,321 servicemen who were demobilized after participating in the anti-terror military operation, and 10,426 members of the families of servicemen of of Ukraine's Armed Forces (Kokun O., Agayev N., Pishko I., 2017, p.5).

There is a problem of staffing in the system of mental health care in Ukraine, it is related to the need for changes in order to provide population with quality assistance, including the strengthening of the role of social workers, ergotherapists, psychologists and psychotherapists in providing mental health care in Ukraine. In order to improve the system of formation and support of professional competencies of mental health specialists, it is necessary to use modern technologies, increase the level of knowledge in the field of mental health, to bring the education of mental health specialists in accordance with modern world standards, to strength the role of mental health specialists due to appropriate changes in the standards of training specialists and the regulation of professional activities, to development international cooperation, to effort the role of public sector, the recognition of role of professional associations in mental health in defining the standards of assistance and training of specialists.

Professional training of social workers in Ukraine is carried out taking into account the leading world models (American, Western European, East European); according to domestic normative and legal acts: Laws of Ukraine "On Education" (1991), "On Higher Education" (2014), "On Professional Development of Employees" (2012), "On Social 
Services" (2003), National Strategy for the Development of Ukraine's Education for the period up to 2021 (2012), "Strategies for sustainable development of Ukraine - 2020" (2015). It focuses on the "World Standards for Education and Training in Social Work" (2004) and "The New Agenda for Social Work in Growth of Global Impact" (2011) as a new concept for the activities of social professionals in the context of the growing effects of globalization on health and the well-being of people caused by the inequality and instability of the environment due to climate change, the impact of hostilities, violence, natural disasters, and pollutants. Representatives of the International Federation of Social Workers (IFSW) and the International Association of Schools of Social Work (IASSW) consider strengthening the role of social workers in helping to improve and strengthen communities through quality of social workers' professional training as an important direction for solving this global problem (Klos L., 2018, p. 38-39).

Regarding this the WHO Global Health Action Program on Mental Health approved by the 55th session of the World Health Assembly in 2002 is valuable, is called on Member States to increase investment in mental health both within and across countries, in bilateral and multilateral cooperation for this purpose (WHA 55.10). As well as the WHO Comprehensive Action Plan on Mental Health for 2013-2020, focusing on which Ukraine is building its state strategy for mental health of the nation. Thus, the Decree of the Cabinet of Ministers of Ukraine No. 1018-r from 27.12.2017 approved the Concept of the Development of Mental Health Care in Ukraine for the period up to 2030 (Cabinet of Ministers of Ukraine, 2017; World Health Organization, 2018).

\section{Propose a specialization educational program for the social workers training for work in the field of mental health in Ukraine}

Taking into account the results of studying the US experience in practical social work in the field of mental health and appropriate professional training (analysis of 28 programs of specialization and mental health concentration for masters and doctors of philosophy in the field of social work), as well as taking into account the current state of affairs problems in Ukraine, the following is proposed. To ensure training of social workers for the mental health field, it is advisable to implement changes at the governmental, sectoral, institutional and university levels.

Prognostic substantiation of the conceptual principles of functioning of the system of social workers' professional training in Ukrainian universities based on progressive experience of the studied country, is carried out in the work. Taking into account progressive ideas of the USA, the educational-methodical complex for improving the system of professional training of future social workers for health-caving activity in higher educational institutions of Ukraine is developed and implemented.

The changes proposed for the state policy, educational policy in particular: the formation of a unified strategy of inter-sectoral, interprofessional solution of the problem of mental health through the enhancement of interaction between the Ministries of Education and Science, Health Care and Social Policy, with the prospect of unification of the Ministry of Health Care and the Ministry of Social Policy into one structure (as it is in most developed countries); launching interprofessional training of social workers for health-care activities and work in mental health care based on cooperation between the Ministry of Education and Science, the Ministry of Health Care and the Ministry of Social Policy; reforming the system of social protection and public services - improving the regulatory framework (legislation, terminology, and financing) that will allow to study social problems of the population, in particular people with mental health problems, and 
seek ways to resolve them with the actual participation of social workers; it will increase the state's attention to the issue of the education of social workers in general and the training of social workers for the health sector and mental health care in particular; legislative approval of the specialization "Social work in mental health care" to ensure participation of mental health social workers within interdisciplinary groups of professionals - health teams; the development of standards of practice for specializations "Social work in health care", "Social work in mental health care" and standards of training (based on the World standards of education in social work and the needs of Ukrainian society) involving representatives of professional organizations; the development of the professional scientific and practical publication "Social work in mental health care" as a scientific and practical platform for interdisciplinary research, initiatives, publications, exchange of experience; creation of educational programs of International Social Work in the field of health (in cooperation with international partners).

For the programs of all levels of training the following changes are required. Selecting applicants for the program should be conducted considering not only the results of external testing, but also interviews, which will enable to understand the applicant's ability to develop as a professional in social work. Increasing the practical component up to $40 \%$ of the program. Diversifying training programs due to their diversity: by the form - distance, distributed learning; by the profile - twofold training (Master of Social Work + Master of Public Health); by the educational level - parallel, simultaneous, and combined degree (Bachelor's + Master's degree, Master's degree + Doctor of philosophy of social work). Using a step-by-step scale (detailed, with a set of criteria for recognition of professional behavior) assessing the level of formation of key and special competencies of students in all training courses, involving teachers of practice and supervisors, as well as student self-assessment. Recording the entire success of students in all disciplines in online mode to provide an overview for the administration and management of the faculty or department, for timely intervention, support and assistance to the student; and specifying the criteria for selecting practice placement sites and expanding their network (Klos L., 2018, p. 428-432).

\section{Conclusions}

A study was conducted on the development of social work in the field of mental health in the USA and the peculiarities of the professional training of social workers in this country. Comparing the results with the state of the problem in Ukraine, it was possible to substantiate the concept of the program of professional training of social workers for activities in the field of mental health for the Ukrainian context. Implementation of the proposed concept requires the introduction of changes at the state, branch, institutional and university levels, in directions - conceptual, politico-legal, organizational and managerial, educational-methodical and information-healthpreserving. A detailed description of these transformations requires a separate illumination. We plan to dedicate our next publication to the disclosure of the essence of the mentioned areas.

\section{References}

Awesome statistics. Fighting and non-combat losses in the Armed Forces during the ATO - infographics. Weekly, July $1^{\text {st }}$ 13:47 URL: http://tyzhden. ua/News/195710. [in Ukrainian]. 
Cabinet of Ministers of Ukraine (2017). Order No.1018 as of 27.12.2017 on the approval of The Concept of the development of mental health care in Ukraine for the period up to 2030. URL: https: //www.kmu.gov.ua/ua/npas/pro-shvalennya-koncepciyi-rozvit. [in Ukrainian].

CalSWEC. (2011). Integrated Foundation \& Advanced Competencies for Public Mental Health in California. URL: http://calswec.berkeley. edu/files/uploads/ docx/ Mental\% 2520Health/02_mh_comps_formatted_final.pdf.

California Social Work Education Center. (2016). CalSWEC Programs \& Initiatives / Integrated Behavioral Health Program. URL: http: //calswec.berkeley.edu/ integratedbehavioral-health-program.

Council on Social Work Education. (2015). Annual Statistics on Social Work Education in the United States. URL: http: //www.cswe.org/ CMSPages/GetFile.aspx?guid=992f629c-57cf-4a74-8201-1db7a6fa4667.

Educational Policy and Accreditation Standards for Baccalaureate and Master's Social Work Programs. (2015). Developed by the Council on Social Work Education. URL: http://www.cswe.org/getattachment/Accreditation / Accreditation-Process/2015-EPAS 12015 EPAS_Web_FINAL.pdf.aspx.

General Assemblies of IASSW and IFSW (2004). Global Standards for Social Work Education and Training. Adelaide, Australia.

Gibelman, M. (2005). What social workers do (2nd ed.). Washington, DC: NASW Press

Klos L. (2018). The theory and practice of training of future social workers for health-caring activities at US universities. (Dissertation for the degree of Doctor of Pedagogical Sciences). The Institute of Pedagogical Education and Adult Education of the National Academy of Pedagogical Sciences of Ukraine, Kyiv. [in Ukrainian].

Kokun O.M., Agayev N.A., Pishko I.O., Lozinskaya N.S., Ostapchuk V.V. (2017). Psychological work with soldiers-ATO participants at the stage of recovery: Methodical manual. K .: NDTS GP Armed Forces, 282 p. [in Ukrainian].

NASW Center for Workforce Studies \& Social Work Practice (2011). Social Workers in Mental Health Clinics \& Outpatient Facilities - occupational profile. Washington, DC: National Association of Social Workers. URL: https: //www.socialworkers.org

The National association of social workers NASW Fact Sheet 2006 http:/ /www.socialworkers.org

United States. Department of Labor. Bureau of Labor Statistics. (2016). Occupational Outlook Handbook. URL: http://www.bls.gov/OOH/community-and-socialservice/social-workers.htm\#tab-4

United States. News \& World Report. (2011). The 50 best careers of 2011. URL http://money.usnews.com/money/careers/articles/2010/12/06/the-50-bestcareers-of-2011.html

World Health Organization (2018). Mental health atlas 2017. Geneva. URL: https://creativecommons.org/licenses/by-nc-sa/3.0/igo 


\section{ВІД ВИВЧЕННЯ ДОСВІДУ СОЦІАЛЬНОЇ РОБОТИ США У СФЕРІ МЕНТАЛЬНОГО ЗДОРОВ'Я ДО ПРОГРАМИ СПЕЦІАЛІЗАЦІЇ СОЦІАЛЬНИХ ПРАЦІВНИКІВ В УКРАЇНІ}

Лілія Клос, доктор педагогічних наук, дочент, кафедра соиіології та соиіальної роботи, Національний університет «Львівська політехніка»,

м. Львів, Україна

klosliliya615@gmail.com

Анотація. Стаття присвячена обгрунтуванню доцільності запровадження нової спеціалізації з підготовки соціальних працівників у Львівській політехніці. Проаналізовано розвиток практики соціальної роботи у сфері ментального здоров'я в США та, з урахуванням сукупності критеріїв, запропоновано авторську періодизачію розвитку системи професійної підготовки соціальних працівників у США до діяльності зі збереження здоров'я населення. Схарактеризовано емпіричний досвід сочіальної роботи у сфері ментального здоров'я в изій краӥні та здійснено його порівняльний аналіз із украӥнськими реаліями. На основі виявлених теоретико-методологічних засад $i$ організаційно-методичних особливостей професійної підготовки соиіальних працівників до надання сочіальних послуг у контексті вирішення проблем охорони ментального здоров'я населення в США, запропоновано проект програми спеціалізації соціальних працівників до діяльності в сфері ментального здоров'я в Україні.

Ключові слова: сочіальна робота; сочіальний працівник; ментальне здоров'я; зарубіжний досвід; діяльність соціального працівника сфери ментального здоров'я; програма професійної підготовки.

\section{Література}

Вражаюча статистика. Бойові та небойові втрати в ЗСУ за час АТО інфографіка. Тиждень, 1 липня, 2017 13:47 URL: http://tyzhden.ua/News/195710

Кабінет Міністрів України (2017). Розпорядження № 1018-р від 27.12.2017 р. про схвалення Концепції розвитку охорони психічного здоров'я в Україні на період до 2030 року. URL: http://zakon2.rada.gov.ua/laws/show/1018-2017

Клос Л. (2018). Теорія і практика професійної підготовки майбутніх соціальних працівників в університетах США до здоров'єзбережувальної діяльності. (Дис. д-ра пед. наук). Інститут педагогічної освіти і освіти дорослих Національної академії педагогічних наук України, Київ.

Кокун O.М., Агаєв Н.А., Пішко I.О., Лозінська Н.С., Остапчук В.В. (2017). Психологічна робота 3 військовослужбовцями - учасниками АТО на етапі відновлення: Методичний посібник. К.: НДЦ ГП ЗСУ, 282 с.

CalSWEC. (2011). Integrated Foundation \& Advanced Competencies for Public Mental Health in California. URL: http://calswec.berkeley. edu/files/uploads/ docx/ Mental\% 2520Health/02_mh_comps_formatted_final.pdf.

California Social Work Education Center. (2016). CalSWEC Programs \& Initiatives / Integrated Behavioral Health Program. URL: http: //calswec. berkeley.edu/ integrated-behavioral-health-program. 
Council on Social Work Education. (2015). Annual Statistics on Social Work Education in the United States. URL: http: //www.cswe.org /CMSPages/GetFile aspx?guid=992f629c-57cf-4a74-8201-1db7a6fa4667.

Educational Policy and Accreditation Standards for Baccalaureate and Master's Social Work Programs. (2015). Developed by the Council on Social Work Education. URL: http://www.cswe.org/getattachment/Accreditation/Accreditation-Process/2015EPAS /2015 EPAS Web FINAL.pdf.aspx.

General Assemblies of IASSW and IFSW (2004). Global Standards for Social Work Education and Training. Adelaide, Australia.

Gibelman, M. (2005). What social workers do (2nd ed.). Washington, DC: NASW Press

NASW Center for Workforce Studies \& Social Work Practice (2011). Social Workers in Mental Health Clinics \& Outpatient Facilities - occupational profile. Washington, DC: National Association of Social Workers. URL: https: // www.socialworkers.org

The National association of social workers NASW Fact Sheet 2006 http:/ /www.socialworkers.org

United States. Department of Labor. Bureau of Labor Statistics. (2016). Occupational Outlook Handbook. URL: http://www.bls.gov/OOH/community-andsocial-service/social-workers.htm\#tab-4

United States. News \& World Report. (2011). The 50 best careers of 2011. URL http://money.usnews.com/money/careers/articles/2010/12/06/the-50-bestcareers -of2011.html

World Health Organization (2018). Mental health atlas 2017. Geneva. URL: https://creativecommons.org/licenses/by-nc-sa/3.0/igo

Стаття надійшла в редакцію: 08 жовтня, 2018 
